\title{
Crustal structure and rift tectonics across the Cauvery-Palar basin, Eastern Continental Margin of India based on seismic and potential field modelling
}

\author{
D Twinkle ${ }^{1}$, G Srinivasa RaO ${ }^{1}$, M Radhakrishna $^{1, *}$ and K S R Murthy ${ }^{2}$ \\ ${ }^{1}$ Department of Earth Sciences, Indian Institute of Technology Bombay, Powai, Mumbai 400 076, India. \\ ${ }^{2}$ CSIR - National Institute of Oceanography, Regional Centre, Lawson's Bay Colony, \\ Visakhapatnam 530 003, India. \\ *Corresponding author.e-mail: mradhakrishna@iitb.ac.in
}

\begin{abstract}
The Cauvery-Palar basin is a major peri-cratonic rift basin located along the Eastern Continental Margin of India (ECMI) that had formed during the rift-drift events associated with the breakup of eastern Gondwanaland (mainly India-Sri Lanka-East Antarctica). In the present study, we carry out an integrated analysis of the potential field data across the basin to understand the crustal structure and the associated rift tectonics. The composite-magnetic anomaly map of the basin clearly shows the onshore-tooffshore structural continuity, and presence of several high-low trends related to either intrusive rocks or the faults. The Curie depth estimated from the spectral analysis of offshore magnetic anomaly data gave rise to $23 \mathrm{~km}$ in the offshore Cauvery-Palar basin. The 2D gravity and magnetic crustal models indicate several crustal blocks separated by major structures or faults, and the rift-related volcanic intrusive rocks that characterize the basin. The crustal models further reveal that the crust below southeast Indian shield margin is $\sim 36 \mathrm{~km}$ thick and thins down to as much as $13-16 \mathrm{~km}$ in the Ocean Continent Transition (OCT) region and increases to around 19-21 km towards deep oceanic areas of the basin. The faulted Moho geometry with maximum stretching in the Cauvery basin indicates shearing or low angle rifting at the time of breakup between India-Sri Lanka and the East Antarctica. However, the additional stretching observed in the Cauvery basin region could be ascribed to the subsequent rifting of Sri Lanka from India. The abnormal thinning of crust at the OCT is interpreted as the probable zone of emplaced Proto-Oceanic Crust (POC) rocks during the breakup. The derived crustal structure along with other geophysical data further reiterates sheared nature of the southern part of the ECMI.
\end{abstract}

\section{Introduction}

The Cauvery-Palar basin is one of the major petroliferous basins located at the southeastern coast of the peninsular India covering the coast (Sastri et al. 1981) between Ramanathapuram near the Palk Strait and the region north of Chennai (figure 1). The basin is characterized by the presence of NE-SW trending horst-graben subsurface basement structural features having a sediment cover of nearly 1-6 km (Rangaraju et al. 1993). The basin is classified as peri-cratonic rift basin and came into existence in late Jurassic as a result of rifting between India and East Antarctica during the fragmentation of the eastern Gondwanaland (Biswas et al. 1993). The basement is mainly composed of

Keywords. Crustal structure; gravity and magnetic; seismic; Cauvery-Palar basin; Eastern Continental Margin of India (ECMI). 


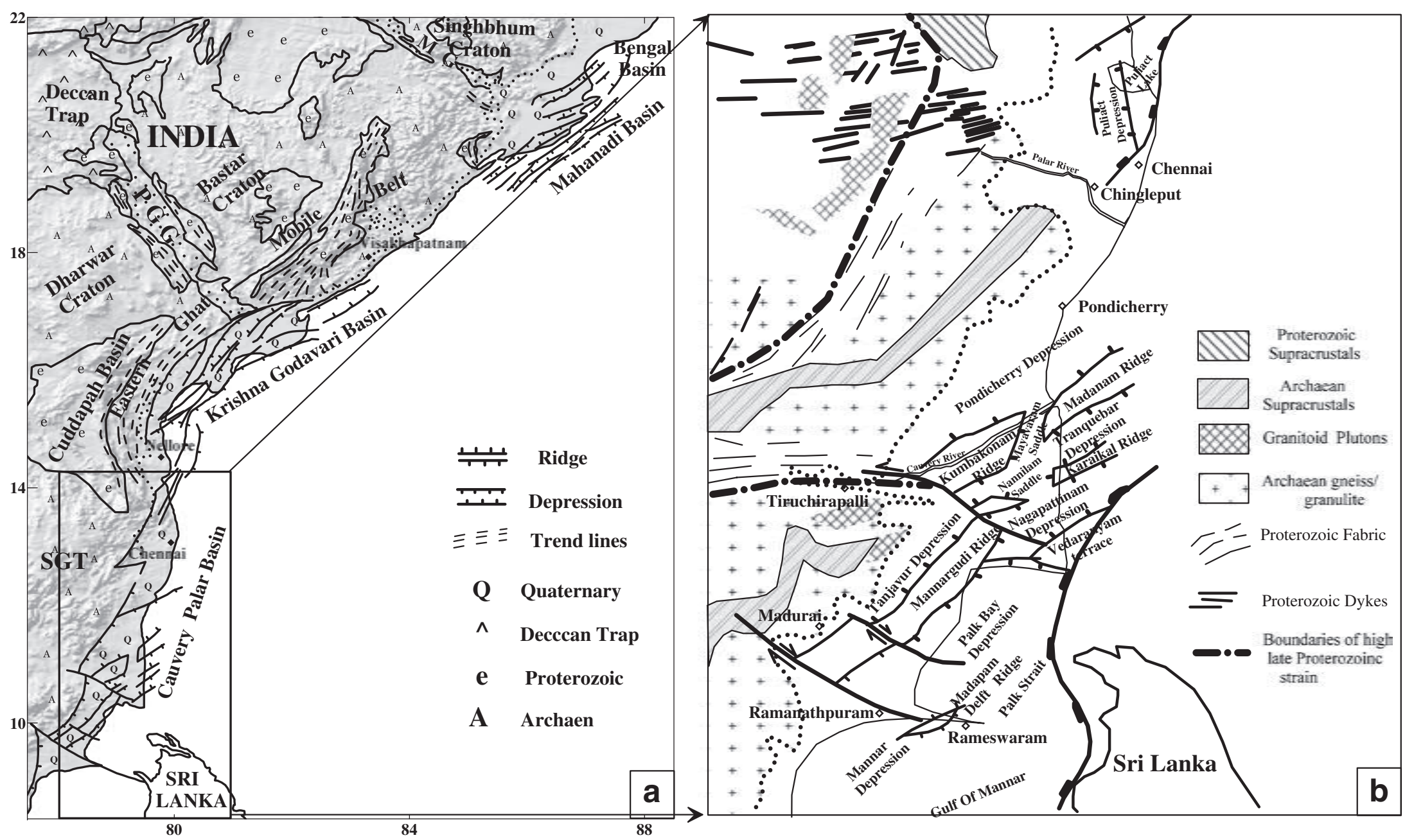

Figure 1. (a) Regional morphotectonic map of the east coast of India (after Lal et al. 2009) showing the location of Cauvery-Palar basin. (b) Geological, tectonic and structural features in the onshore and the offshore Cauvery-Palar basin. The onshore geology is compiled from Drury et al. (1984). Tectonic details are compiled from Prabhakar and Zutshi (1993) and Biswas et al. (1993). 
Archean metamorphic and igneous rocks, and the Eastern Ghat rocks comprising of charnockites, quartzites, granitic gneiss and schists (Sastri et al. 1981; Sahu 2008). The subsurface structure and the tectono-stratigraphic history of the CauveryPalar basin is well known from the previous geophysical investigations (Sastri et al. 1973, 1981; Kumar 1983; Chandra et al. 1993; Prabhakar and Zutshi 1993; Rangaraju et al. 1993; Sahu 2008; Lal et al. 2009; Bastia and Radhakrishna 2012). The basin encompasses vast offshore segment and continues into the deep water areas of the eastern offshore of India (Bastia et al. 2010). On the basis of offshore magnetic anomalies, Subrahmanyam et al. (2006) inferred the continuation of onshore Precambrian structural grain/major lineaments in the Cauvery offshore. In the adjoining KrishnaGodavari basin, integration of Deep Seismic Sounding (DSS) studies in the onshore (Kaila et al. 1990) and the multi-channel seismic (MCS) reflection profiles in the offshore (Radhakrishna et al. 2012a) along with the gravity interpretation provided valuable information of the crustal structure and early breakup history in the central segment of the Eastern Continental Margin of India (ECMI). However, in the Cauvery-Palar basin, so far, no such integrated analysis in terms of crustal structure has been made. In the present study, we undertake a detailed interpretation of the available geophysical data in both onshore and offshore Cauvery-Palar basin in order to delineate crustal structure as well as to understand the breakup history in the southern part of ECMI.

\section{Regional tectonic set-up}

The Cauvery-Palar basin is one of the major pericratonic rift basins along the east coast of India that have developed during the rift-drift events associated with the breakup of India from the east Antarctica. The Precambrian rocks of the Southern Granulite Terrain (SGT) and the rocks belonging to the Eastern Ghat Mobile Belt (EGMB) limit the basin in the west. While, Nayudupetta high separates the Palar from the Pennar basin in the north, the Sri Lanka massif limits the basin in the south. Towards east, the basin extends into the offshore having nearly $33,000 \mathrm{~km}^{2}$ area up to $200 \mathrm{~m}$ isobath and more than $95,000 \mathrm{~km}^{2}$ area in the deep water, and finally merges with the pure oceanic domain of the Bay of Bengal (Rangaraju et al. 1993; Bastia and Radhakrishna 2012). According to Prabhakar and Zutshi (1993), the basin is characterized by Jurassic-early Cretaceous pattern of normal faults along NE-SW trending horsts and graben and these trends are in conformity with the Eastern Ghats trend. The major structural and tectonic elements observed in the Cauvery-Palar basin (after Prabhakar and Zutshi 1993; Bastia and Radhakrishna 2012) are: (i) Pulicat depression defined by Nayudupetta high in the north and Chingleput high in south in the Palar basin, (ii) Ariyalur-Pondicherry and Tanjavur-Tranquebar depressions separated by Kumbhakonam-Madanam ridge, (iii) Nagapattinam depression limited by Karaikal ridge on the north and Vedaranyam terrace in south, (iv) Palk Bay and Tanjavur depressions separated by Mannargudi ridge, (v) Pamban depression separated by Mandapam-Delft ridge from Palk Bay, and (vi) Mannar depression further west in Gulf of Mannar. Detailed seismic investigations in the offshore areas of the basin revealed that some of the major onshore depressions such as the Pondicherry, Tranquebar, Nagapattinam and Mannar continue into the deep oceanic regions, whereas, the Palk bay is bounded by Indian and Sri Lankan massifs (Sahu 2008). The subsurface mapping in this basin further revealed that two prominent cross trends such as the Vedaranyam-Tiruchirapalli and MaduraiRameswaram cut across the general NE-SW trending rift related horst-graben structural features (Prabhakar and Zutshi 1993). Some of the Precambrian structural elements such as the PalghatCauvery and Moyar-Bhavani shear zones extend into the offshore (Subrahmanyam et al. 2006). Morphotectonic studies in the offshore areas further revealed the signatures of recent deformation (Ramasamy and Balaji 1995) and differential tectonic movements off Pondicherry (Ramasamy et al. 2001).

\section{Datasets and map preparation}

\subsection{Topography map}

The topographic map of the Cauvery-Palar basin (figure 2a) is prepared from the DNSC08 predicted bathymetry in the offshore (Andersen and Knudsen 2008) and GTOPO30 elevation data in the onshore region. As can be seen, entire onshore part of the basin is mostly characterized by elevation below $200 \mathrm{~m}$ and this contour demarcates the basin from the adjoining crystalline rocks. In the offshore, the shelf is wider north of Pondicherry up to Chennai as well as off Vedaranyam, while the shelf-slope part is seen to be protruding towards the coast between Karaikal and Pondicherry (figure 2a). Presence of submarine canyons off Cuddalore and Pondicherry were reported from earlier bathymetric studies (Varadachari et al. 1968; Bastia et al. 2011). While major valleys off Pondicherry have formed due to the existence of mega-lineaments (Rao et al. 1992), the marine geophysical studies in general 

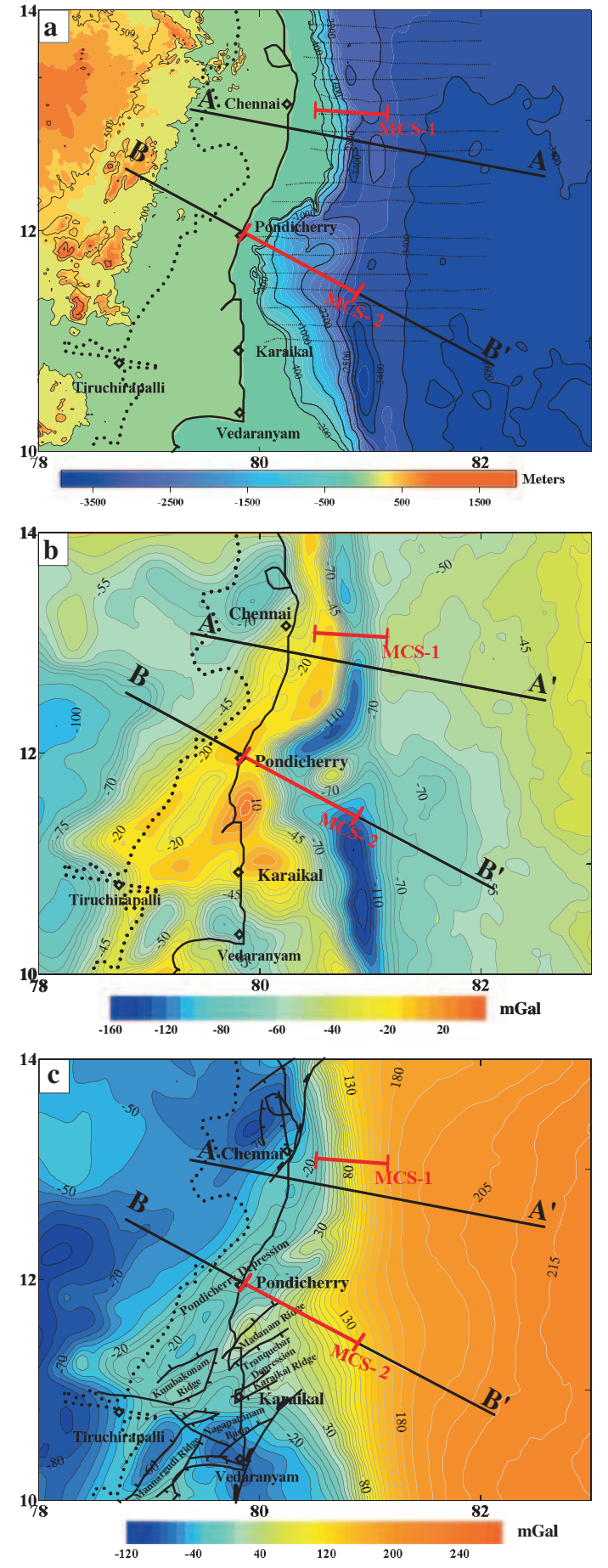

Figure 2. (a) Topography map of the Cauvery Basin prepared from the GTOPO30 global relief database in the onshore and the DNSC08 predicted bathymetry data (Andersen and Knudsen 2008) in the offshore. Location of ship-borne magnetic data (thin lines) utilized in the present study are also shown. (b) Gravity anomaly map with Bouguer anomalies (Verma et al. 1993) in the onshore and satellite-derived free-air anomalies (Andersen and Knudsen 2008) in the offshore. (c) Complete Bouguer anomaly map of the basin after employing the Bouguer slab correction and terrain correction to the data in (b) along with tectonic elements. MCS1 and MCS2 (red lines) are multi-channel seismic reflection lines utilized in the present study. AA' and BB' are the regional transects across the margin considered for gravity and magnetic modelling. revealed that lineaments played an important role in shaping the shelf-slope morphology apart from other geological processes (Murthy et al. 2012 and the references therein). Further, the deep offshore morphology is characterized by very steep continental slope that is distinctly different from rest of the ECMI. This characteristic morphological expression of the shelf-slope areas of this margin caused the higher run-up heights and inundation along the Nagapattinam-Cuddalore coast during the 26 December 2004 major tsunami event (Murthy et al. 2006, 2012). Further, the Cauvery offshore is also characterized by the occurrence of marine geohazards such as the slope instability and slope canyons (Bastia et al. 2011).

\subsection{Gravity anomaly map}

For the preparation of gravity anomaly map of the Cauvery-Palar basin, the Bouguer anomaly map available in the onshore (Verma et al. 1993) is used. In the offshore part of the basin, ship-borne gravity data are very sparse and available only along few profiles. However, the DNSC08 version of the highresolution 1' $\times 1$ 's satellite-derived free-air gravity data (Andersen and Knudsen 2008) provides dense and uniform coverage in the offshore areas. This version of satellite-derived gravity data has improved resolution in coastal areas and contains information down to $20 \mathrm{~km}$ wavelength (Andersen and Knudsen 2008). Also, for the scale of structural features in the region, the satellite gravity data are comparable with the ship-borne gravity measurements. The merged onshore Bouguer gravity and the offshore free-air gravity anomalies in the Cauvery-Palar basin present an excellent continuity of gravity closures at the coast and their trends into the shelf area (figure 2b). The Bouguer anomalies in the onshore clearly reveal various gravity highs and lows associated with the ridge-depression features of the basement that was mapped from the seismic as well as subsurface litholog data (e.g., Prabhakar and Zutshi 1993). Large negative Bouguer anomalies of the order of $-100 \mathrm{mGal}$ are observed in the crystalline part of the Indian shield crust in the western part of the map. In the offshore, the shelf edge gravity anomaly can be clearly noticed with two prominent gravity lows of the order of $-140 \mathrm{mGal}$ following the shelfslope morphology off Pondicherry and Vedaranyam regions and these two lows are separated by gravity high (figure $2 \mathrm{~b}$ ). From the topography and free-air anomaly map (figure $2 \mathrm{a}$ and $\mathrm{b}$ ), we computed the complete Bouguer anomalies using the Bouguer and terrain corrections by replacing the water layer with an average continental crustal rock density of $2.80 \mathrm{gm} / \mathrm{cc}$. The resulting complete Bouguer anomaly map (figure 2c) in general shows 
an inverse relationship with bathymetry, i.e., an increase in the Bouguer anomalies with increasing bathymetry due to the isostatic compensation effect of Moho geometry and the resulting crustal thinning towards offshore.

\subsection{Composite magnetic anomaly map}

For better understanding of structural and tectonic features in the onshore and offshore parts of the basin, we prepared a composite magnetic anomaly map by combining the aeromagnetic data in the onshore and ship-borne magnetic data in the offshore parts of the Cauvery-Palar basin (figure 3). The onshore total field magnetic anomaly map is presented from the available aeromagnetic anomaly map of south India (after Rajaram et al. 2006) which was prepared based on the aeromagnetic data acquired by the National Remote Sensing Agency (NRSA) during the period 1980-1994 at altitudes of $5000 \mathrm{ft}$ and flight line spacing of $4 \mathrm{~km}$ under the National Program of Aeromagnetic Surveys. On the other hand, the total field magnetic anomaly map for the offshore region of the Cauvery-Palar basin is prepared utilizing the 16 ship-borne magnetic profiles available from the National Institute of Oceanography (NIO) track line database (see figure 2a for location of profiles). The composite magnetic anomaly map (figure 3) reveals the extension/continuity of several magnetic anomaly highs/lows from the onshore towards the offshore. In the onshore part, the colour coded aeromagnetic anomaly map clearly demarcates the anomaly pattern over the Precambrian crystalline from that of the sedimentary basin region in the east. The structural trends and regional geotectonic features such as Archean supra-crustal rocks, dykes, migmatitic rocks compiled from Drury et al. (1984) correlate well with the magnetic anomaly trends in the shield region. The trends of major shear zones such as Moyar-Bhavani and PalghatCauvery are clearly revealed on the aeromagnetic anomaly map in the onshore (Reddi et al. 1998). Subrahmanyam et al. (2006) identified three major faults (marked F1, F2, and F3 in figure 3) cutting across the $\mathrm{E}-\mathrm{W}$ trending shear zones in the onshore and extension of these structural trends into the Cauvery offshore. Additionally, in the offshore, a broad magnetic low ( $\sim-200 \mathrm{nT})$ bounded by highs on either side (in north and south) is noticed between Mahabalipuram and Chennai. Though not clearly distinguishable, this low seems to be having its expression further interior of the coast. Qualitative interpretation of three magnetic profiles falling within this broad low zone revealed that the region is characterized by intrusives with high magnetization contrast and the $\mathrm{E}-\mathrm{W}$ trending magnetic high off
Cuddalore as associated with the graben structure (Murthy et al. 1993, 2012). Therefore, from the magnetic signatures, it can be inferred that the crust in the Cauvery-Palar basin is highly fragmented or blocky in nature and is separated by several faults/fractures. For further analysis of the structure (both upper crust as well as deep structure), we have considered two regional transects passing through major structures in the Cauvery-Palar basin across the margin (AA' and BB' in figure $2 \mathrm{~b}$ ) for $2 \mathrm{D}$ gravity and magnetic modelling.

\subsection{Multi-channel seismic (MCS) reflection profiles in the offshore}

Based on the detailed analysis of seismic data in the offshore Cauvery-Palar basin, Balakrishnan and Sharma (1981) identified a series of horstgraben features that are oblique to the coast. The seismic data indicated that the grabens are filled with Mesozoic sediments and the Tertiary sediments brought by the Cauvery river system formed thick sedimentary wedge on the eastward sloping platform (Prabhakar and Zutshi 1993; Sahu 2008). Here, we present two MCS reflection profiles MCS1 and MCS2 (see figure 2a for their location) across the Cauvery-Palar basin. While, MCS1 is a part of the regional seismic profile MAN-03 (after Gopala Rao et al. 1997; Krishna et al. 2009) that passes along $13^{\circ} \mathrm{N}$ latitude in the Palar offshore, MCS2 located in the Cauvery offshore (after Bastia et al. 2010) is one of several regional deep reflection seismic lines acquired by GX Technology in the eastern offshore. The two seismic sections and the gravity and magnetic anomalies along these profiles are presented in figure 4 . As can be seen, both the seismic profiles have imaged some of the rift-related structures at the margin. For example, the prominent basement high and the Mesozoic sediments abutting against this high can be observed in the seismic section MCS2 in the Cauvery offshore (after Bastia et al. 2010). Another interesting aspect observed in both seismic sections is the presence of steep slope at this margin. The presence of relatively low angle normal faults with throws as much as 3 Sec TWT and a major fault coinciding with the steep continental slope can be noticed in the seismic section MCS1 (after Krishna et al. 2009).

\section{Analysis and results}

\subsection{Estimation of depth to Curie isotherm}

The Curie isotherm depth is defined as the depth (corresponds to $580^{\circ} \mathrm{C}$ for magnetite) at which the rock loses its ferromagnetic magnetization under the effect of increasing temperature. Therefore, 


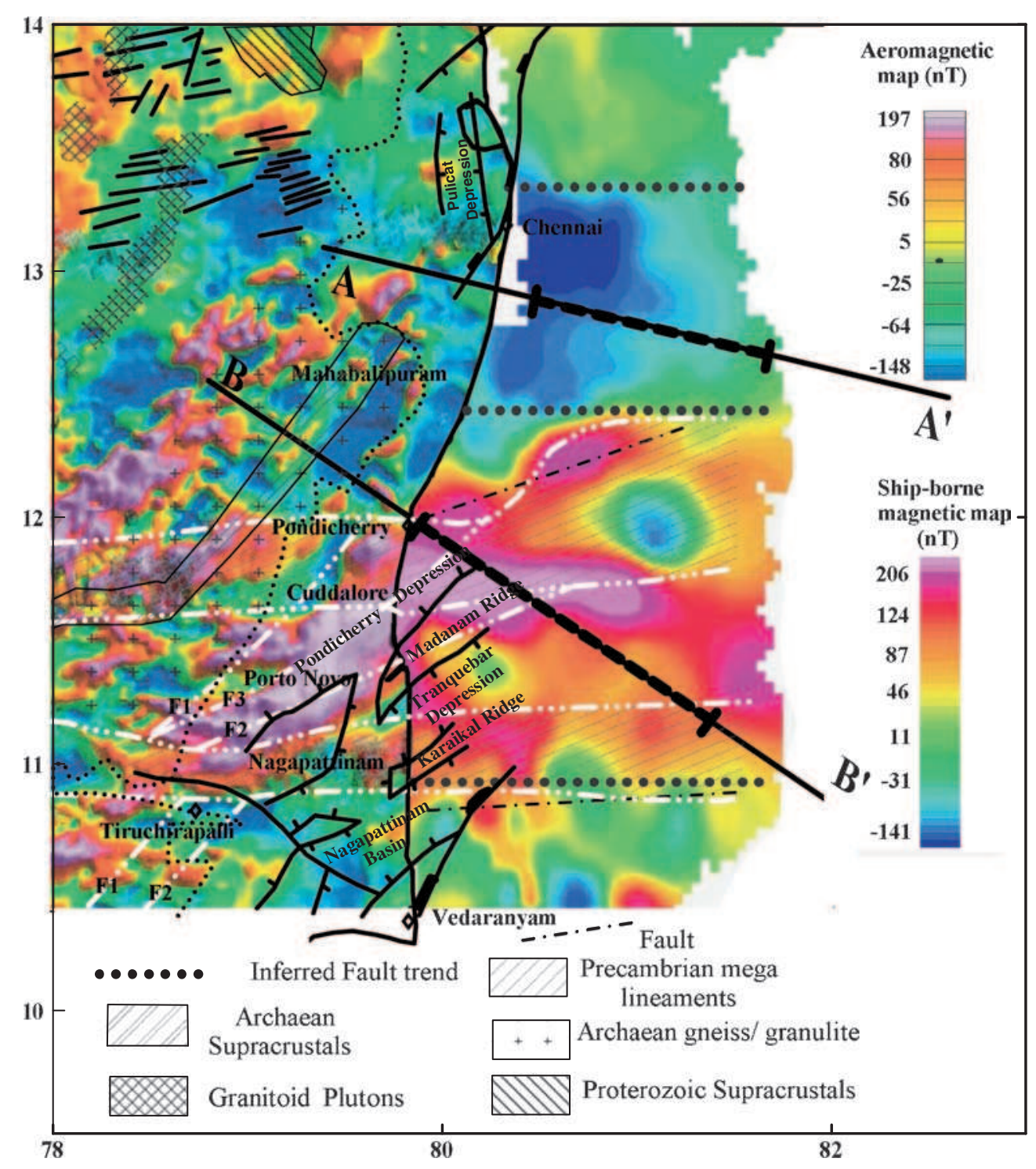

Figure 3. Composite total field magnetic anomaly map of the Cauvery-Palar basin region prepared using the aeromagnetic anomaly map in the onshore region (after Rajaram et al. 2006) and the ship-borne magnetic data in the offshore region (in this study). Tectonic details (after Prabhakar and Zutshi 1993), onshore geologic trends (after Drury et al. 1984) and offshore continuation of Precambrian mega-lineaments (after Subrahmanyam et al. 2006; Muthy et al. 2012) are presented. AA' and BB' are regional transects across the margin considered for gravity modelling with part of transects (dashed lines) considered for joint gravity-magnetic modelling.

the depth to the bottom of magnetic source estimated from magnetic anomaly data can be used as a proxy to constrain the Curie isotherm depth (Bhattacharyya and Leu 1975; Okubo et al. 1985; Blakely1995; Tanaka et al. 1999; Ross et al. 2006; Ravat et al. 2007; Rajaram et al. 2009; Bansal et al. 2011). Recently, Rajaram et al. (2009) prepared the Curie isotherm map of the Indian subcontinent from the satellite and aeromagnetic data using spectral peak method (Blakely 1995). According to their study, the Curie depths estimated for the onshore part of Cauvery-Palar basin ranges from $26 \mathrm{~km}$ at the coast to $30 \mathrm{~km}$ within the crystalline rocks. In the present study, we have estimated the Curie isotherm depths for the offshore part of Cauvery-Palar basin following the method of Tanaka et al. (1999) and it was originally developed by Okubo et al. (1985) based on the technique of Spector and Grant (1970). According to Blakely (1995), the radial averaged power spectral density $P(k)$ of a magnetized body having infinite extensions in the horizontal direction and depth to the top of the body is small compared with the horizontal scale of a magnetic source which can be written as:

$$
P(k)=A e^{-2|k| Z_{t}}\left(e^{-|k|\left(Z_{b}-Z_{t}\right)}\right)^{2}
$$

where $k$ is the wave number, $A$ is a constant related to magnetization direction and geomagnetic field 



Figure 4. Regional multi-channel seismic profiles MCS1 (after Krishna et al. 2009) and MCS2 (after Bastia et al. 2010) across the offshore Cauvery-Palar basin showing prominent basement highs, intervening basins and thick column of Tertiary sediments in the deep offshore region of the ECMI. The gravity and magnetic anomalies along these profiles are shown in the above panels along the seismic sections.

direction, and $Z_{t}$ and $Z_{b}$ are depths to the top and bottom of magnetic sources, respectively.

At middle-high wave number band, where wavelengths less than about twice the thickness of the magnetic source, equation (1) can be approximated as:

$$
\ln (P(k))=\ln B-2|k| Z_{t} .
$$

At low-wavenumber band, equation (1) could also be written as:

$$
\ln \left(\frac{P(k)}{k}\right)=\ln C-2|k| Z_{0} .
$$

Further, the depth to the top $\left(Z_{t}\right)$ and the centroid depth $\left(Z_{0}\right)$ of the magnetic source could be estimated from the slopes of the radially averaged power spectrum obtained from equation (2) and wavenumber-scaled power spectrum (equation 3), respectively. Finally, the depths to the bottom of the magnetic source (Curie isotherm depth) can be derived (Okubo et al. 1985; Tanaka et al. 1999) using the equation

$$
Z_{b}=2 Z_{0}-Z_{t}
$$

Here, the radially averaged power spectrum and wavenumber-scaled power spectrum were computed for the available ship-borne magnetic anomaly grid using equations (2) and (3) respectively (figure 5). Further, the centroid depth $\left(Z_{0}\right)$ and depths to the top $\left(Z_{t}\right)$ of the magnetic source were estimated from the slopes of the regression lines fitted for wavenumber-scaled power spectrum in $0.005-0.05 \mathrm{~km}^{-1}$ wavenumber-band and radially averaged power spectrum in $0.05-0.09 \mathrm{~km}^{-1}$ wavenumber band (figure 5). It gave rise to a depth of $8.0 \mathrm{~km}$ for $Z_{t}$ and $15.8 \mathrm{~km}$ for $Z_{0}$. Finally, the depth to the bottom of the magnetic source (Curie isotherm depth) $Z_{b}$ was estimated using equation (4), which is around $23.6 \mathrm{~km}$.

\subsection{Constrained potential field modelling}

The crustal structure variation across the margin is modelled through $2 \mathrm{D}$ gravity and magnetic modelling along the regional transects $\mathrm{AA}^{\prime}$ and BB' (figure 2b). These transects are chosen in line with the available seismic profiles MCS1 and MCS2 (figure 4) in the offshore. The basement 



Figure 5. Power spectrum (left panel) and wavenumber-scaled power spectrum (right panel) computed from the offshore magnetic anomaly grid. $Z_{t}$ and $Z_{0}$ are the depth to the top of magnetic source and centroid depth estimated from the slopes of the regression lines fitted to the power spectrum and wave number-scaled power spectrum respectively (see section 4.1 for details). $Z_{b}$ represents the depth to the bottom of the magnetic source.

structure obtained along the MCS profiles is projected onto these lines for modelling. Also, the profiles have been constrained by projecting the basement depth information from available sediment thickness maps in the onshore (Prabhakar and Zutshi 1993) and in the offshore (Radhakrishna et al. 2010). For carrying out $2 \mathrm{D}$ gravity modelling, the gravity values from the complete Bouguer anomaly grid (figure 2c) have been projected. Removal of sediment effect from the complete Bouguer anomaly gave rise to the crustal Bouguer anomaly along these transects for further modelling. Since, water and sediment layer effects have already been removed in the crustal Bouguer anomalies; we need to account for the variations in crustal thickness and/or density heterogeneities while modelling the crustal Bouguer anomaly. In order to model crustal structure along these transects, the seismic velocity structure (the corresponding density values) and the crustal layering information would be useful as an additional constraint. For this purpose, the DSS data available from the previous studies in the southern Indian shield have been compiled. These are: (i) the N-S trending Kuppam-Palani geotransect located across the transition zone between the granite-greenstone terrain in the north and the high-grade gneiss and granulites in the south, where, well controlled seismic refraction-reflection data is available from Reddy et al. (2003) and (ii) the E-W trending Kavali-Parnapalle profile (Kaila et al. 1979; Kaila and Tewari 1985) and the Alampur-Koniki-Ganapeswaram profile (Kaila and Tewari 1985) across the Cuddapah basin.

A detailed evaluation of seismic data and the derived gravity model along the Kuppam-Palani transect (Reddy et al. 2003; Singh et al. 2003) revealed a four-layered crustal configuration with a low density mid-crustal layer and Moho varying from $41 \mathrm{~km}$ below Kuppam to $43-44 \mathrm{~km}$ towards south. As this geo-transect runs across the NE trending Dharmapuri paleo-rift and the E-W trending Palghat-Cauvery shear zone (Mahadevan 2003), the low density mid-crustal layer and the thickened crust had resulted from the emplacement of large volumes of granitic rocks and alkaline plutons indicating intense crust-mantle interactions (Singh et al. 2003). Further, comparison of crustal structure in different parts of the SGT indicated that the seismic data and the derived crustal layering might not be representative of the SGT crust (Ajayakumar et al. 2006). On the other hand, the DSS profiles across the Cuddapah basin (Kaila and Bhatia 1981; Kaila and Tewari 1985) revealed four layered velocity structure for the eastern Indian shield crust with Moho mapped at a depth of $35-39 \mathrm{~km}$ in the Cuddapah basin. Based on these data, Radhakrishna et al. (2012a) defined gross crustal density layering for the Cuddapah basin and the adjoining EGMB with layers defined by $2.7 \mathrm{gm} / \mathrm{cc}(5.3-6.2 \mathrm{~km} / \mathrm{s})$ for the upper crust, $2.75 \mathrm{gm} / \mathrm{cc}(6.3-6.5 \mathrm{~km} / \mathrm{s})$ for the middle crust, and $2.85 \mathrm{gm} / \mathrm{cc}(6.8-6.9 \mathrm{~km} / \mathrm{s})$ for the deep crustal layer and the presence of a higher velocity layer $(>7.2 \mathrm{~km} / \mathrm{s})$ due to magmatic underplating in the deeper part of the crust above Moho. Here, we adopted this gross density layering for the Cauvery basin due to its close proximity except for the presence of high-density underplating layer observed below Cuddapah basin due to magmatic occurrence. However, we do not envisage the continuity of EGMB rocks below Cauvery basin and believe that crust in this region belong to the SGT. For 
the adjoining oceanic crust, the seismic velocities in the western BOB region (Curray et al. 1982) suggest a two-tier density layering; the oceanic volcanic layer having a density of $2.70 \mathrm{gm} / \mathrm{cc}$ $(5.7-6.2 \mathrm{~km} / \mathrm{s})$, and the oceanic igneous crust with a density of $2.90 \mathrm{gm} / \mathrm{cc}(6.8-7.3 \mathrm{~km} / \mathrm{s})$. The seismic velocities in the upper mantle (below Moho) range between 8.1 and $8.2 \mathrm{~km} / \mathrm{s}$ below continental crust and $7.9-8.2 \mathrm{~km} / \mathrm{s}$ below oceanic crust at the ECMI (Radhakrishna et al. 2012a). The density for this layer is assigned a uniform value of $3.3 \mathrm{gm} / \mathrm{cc}$.

Apart from gravity modelling, for part of these transects in the offshore (see figure 3), we carried out joint gravity-magnetic interpretation by projecting magnetic anomalies from the total field magnetic anomaly grid prepared using the NIO ship-borne magnetic data. Though the composite magnetic anomaly map revealed excellent correlation of structural trends across the coast, due to lack of gridded aeromagnetic data, we could not continue the profiles towards onshore. Even if available, the onshore aeromagnetic anomaly data must be brought down to the sea level through downward continuation before carrying out the profile interpretation. For 2D magnetic modelling, the total magnetic field of $40200 \mathrm{nT}$, inclination $5^{\circ}$ and declination $2.25^{\circ}$ are considered and the modelling has been carried out up to the Curie depth $(\sim 23 \mathrm{~km})$ estimated in this study. The susceptibility values for the upper crustal rocks are considered between 0.002 and $0.006 \mathrm{cgs}$ units, whereas, a constant susceptibility of 0.0015 cgs units is considered for the lower crust. Profile azimuth is considered around $120^{\circ}$ for all three profiles. At few locations, rocks with high magnetic susceptibility as well as remnant magnetization have been considered in order to explain the anomaly variations.

While the gravity modelling is used to delineate the deeper structural information, the magnetic interpretation provided information about the magmatic intrusive rocks and the upper crustal rocks. The crustal models generated along transects AA' and BB' are shown in figure 6 . The remnant magnetization (paleo inclination and declination) values of $-62^{\circ}$ and $210^{\circ}$ are used for the intrusive rocks while modelling the magnetic anomalies. The models also indicate the structural continuity of mega shears and other major faults that segment the upper crust. However, it is not clear at this stage whether any of these faults/shears continue deeper into the lower crust; though models indicate they are not. Further, the models delineated the geometry of the thinned rifted continental crust as well as the transition to oceanic crust at the margin (figure 6). The crustal geometry at the coast indicates faulted nature of the Moho. The existence of
Proto-Oceanic Crust (POC) in the deep offshore part of the margin is constrained by seismic interpretation of Nemcok et al. (2012) along the ECMI. In order to further resolve the structural continuation and tectonics of the deep offshore part of the margin, we prepared First Vertical Derivative (FVD) map of the complete Bouguer anomaly map (figure 2C) and presented in figure 7. Since FVD map enhances the shallow crustal and basement related features, the superposition of onshoreoffshore structural trends on this map show excellent correlation and continuity.

\section{Discussion}

The crustal models generated from gravity and magnetic modelling have provided new information about the nature of crustal rocks and the crustmantle interface at the southeast continental margin of India. The models (AA' and BB') indicate that the crust below southeast Indian shield margin is $\sim 36 \mathrm{~km}$ thick and thins down to as much as $13-16 \mathrm{~km}$ in the Ocean Continent Transition (OCT) region and increases to around 19-21 km towards deep oceanic areas. This raise in the Moho is correlated with a change in the crustal Bouguer anomaly.

Based on high-resolution seismic imaging, Nemcok et al. (2012) identified the presence of POC rocks all along the ECMI. The POC rocks form a wider zone at the OCT with variable width along the margin. In the Krishna-Godavari offshore, Radhakrishna et al. (2012a) have further analyzed the reported POC rocks and compared with residual gravity anomalies and magnetic signatures. According to these authors, the boundary between continental crust and POC rocks correlates with a gravity high zone, whereas, the boundary between POC rocks and the oceanic crust did not show any marked variation suggesting that unless the emplaced POC rocks give rise to sufficient density/ susceptibility contrast, potential field data may fail to identify these rocks. Also, we believe that POC rocks may not be pervasive all along the margin and largely depend on the tectono-magmatic history of different segments of the margin during the breakup. The crustal models presented in figure 6 reveal a zone of anomalous crustal thinning which we considered as indicative of the presence of POC rocks. The FVD map in figure 7 did not bring out a distinct gravity zone associated with the POC rocks, however, the boundary between continental crust and the POC correlates with gravity high though not distinct everywhere.

Both the crustal models across the margin reveal faulting in Moho geometry and abrupt thinning with maximum stretching observed in the Cauvery 



Figure 6. 2D crustal models along the transects AA' and BB' (see figure 2b for location) obtained through constrained potential field modelling. The seismic lines MCS1 and MCS2 are projected respectively along these profiles to constrain the models. The rectangles shown on both these models represent the segment for which joint gravity-magnetic interpretation is carried out. OL: Oceanic Layer; POC: Proto-Oceanic Crust; OCT: Ocean continent transition zone. 
basin. This abrupt thinning of crust can be related to shearing or low angle rifting at the time of breakup between India-Sri Lanka and the East Antarctica. The presence of pull-apart basin geometry and the structural high observed in section MCS1 further support the characteristics of sheared margin (Edwards et al. 1997; Krishna et al. 2009). In the onshore Cauvery basin, Rangaraju et al. (1993) have mapped a wrench corridor that cuts across the NE-SW trending horst-graben basement configuration, which depicts the shearing motion. The gravity anomaly trends and the shelf-slope geometry (Mukhopadhyay and Krishna 1991; Subrahmanyam et al. 1999; Krishna et al. 2009), the limited stretching experienced at the margin (Chari et al. 1995), the admittance signatures (Chand et al. 2001), the weaker lithosphere at the
Cauvery basin (Chand and Subrahmanyam 2001) and the mapped fracture zones in the deep offshore within the pure-oceanic domain (Radhakrishna et al. $2012 \mathrm{~b}$ ) all point towards the sheared nature of the Cauvery-Palar segment of the ECMI. However, the additional stretching observed in the Cauvery basin region (BB' in figure 6) could be ascribed to the subsequent rifting of Sri Lanka from India.

Subrahmanyam et al. (1999) inferred that the ECMI is composed of northern rifted and southern sheared segments and ascribed it to the nature of breakup between India and East Antarctica. Subsequently, due to the necessity to accommodate the Elan Bank continental crustal fragment at the ECMI, the two-stage breakup between India and East Antarctica was proposed by Gaina et al. (2007). Further geophysical studies along the
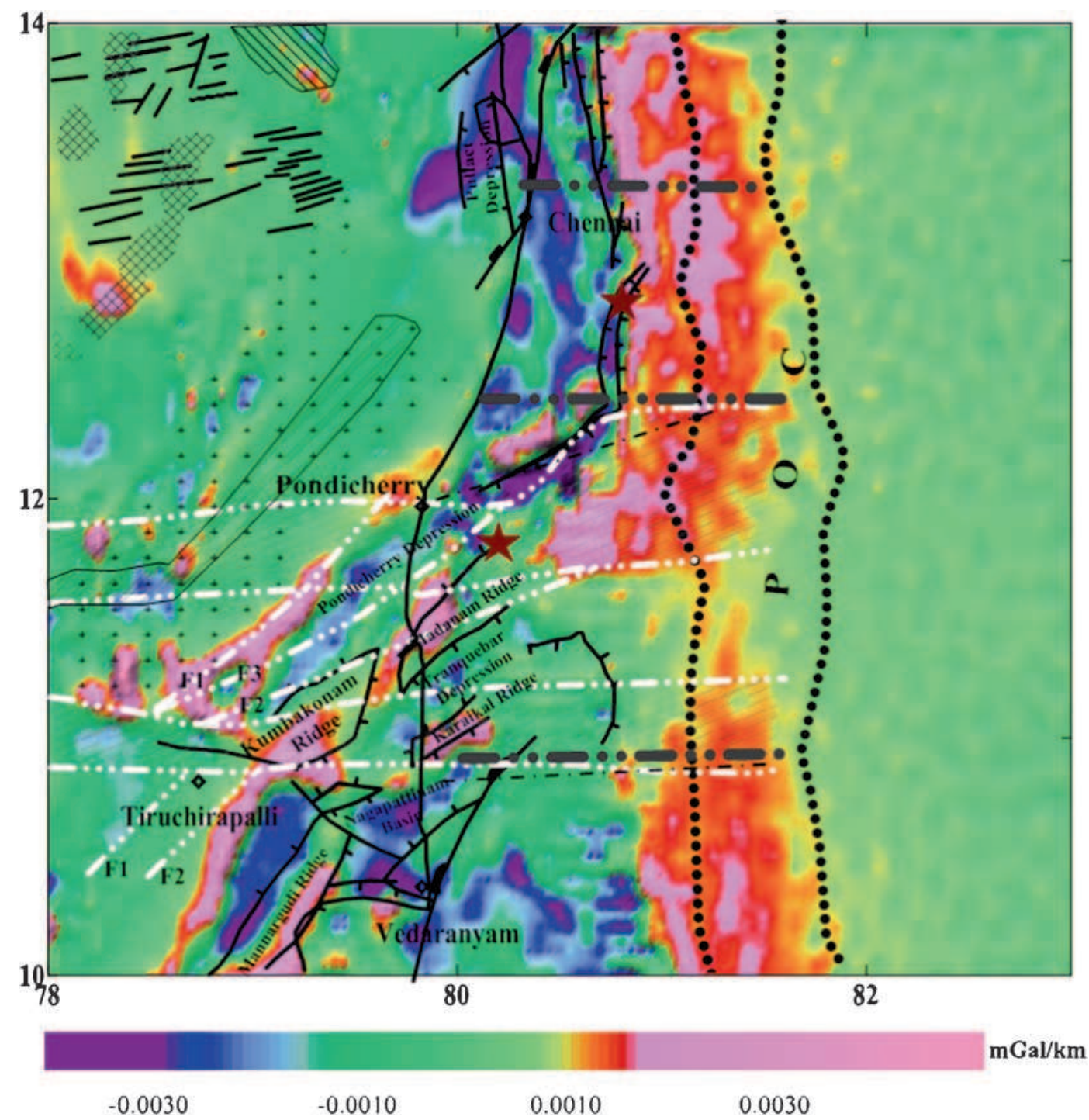

Figure 7. First vertical derivative map of complete Bouguer anomaly map (figure 2c) and the superposed tectonic elements in the Cauvery-Palar basin region. Other details are as in figure 1(b). Stars indicate the locations of the intrusive bodies modelled from the joint gravity-magnetic interpretation (see figure 6). The extent of POC in the offshore is marked from Nemcok et al. (2012) and extended further south from the trend of gravity anomalies. 
ECMI (Krishna et al. 2009; Radhakrishna et al. 2012a, b) supported the double breakup scenario at the margin. These models also involved shearing/oblique rifting for the breakup between southern part of ECMI (Cauvery basin segment) and the western Enderby Basin.

The composite magnetic anomaly map and the crustal models presented in this study reveal that crust in the Cauvery offshore region is mostly segmented due to the presence of $\mathrm{E}-\mathrm{W}$ trending mega shear structures (Moyar-Bhavani and PalghatCauvery) and other major faults which reveal the blocky nature of the upper crust. The continuity of the Precambrian structural trends can also be used to map the location of OCT (figure 7) at the margin. Further, the offshore areas south of Nagapattinam and north of Pondicherry, the high amplitude anomalies observed in the magnetic anomaly map were interpreted due to rift related dyke intrusions (Subrahmanyam et al. 1995) similar to those observed elsewhere along the ECMI (Murthy et al. 1993). Presence of several major shear trends, faults and intrusive structures suggests block-faulted nature of the upper crust in the Cauvery offshore, and such a structure may have implications on the seismogenesis of the region. The 25 September 2001, M5.5 earthquake in the Pondicherry offshore occurs over the fault zone along the extension of the Moyar-Bhavani shear zone (Murty et al. 2002), and its fairly large size in a stable continental region and thrust faulting mechanism (Rastogi 2001) indicate the reactivation of the extended Precambrian structure. Alternately, this earthquake might be also viewed in the context of a sheared margin, as it is located close to the $80^{\circ} \mathrm{E}$ shear zone, along which the southern east coast trends N-S (Chandra 1977). Murthy et al. (2006) observed that the major inundation due to the Indian Ocean Tsunami surge following the $26^{\text {th }}$ December, Sumatra earthquake is due to the fault controlled nature of the Cauvery basin, with a concave shelf between Pondicherry and Nagapattinam. According to their study, the presence of numerous submarine canyons in the offshore Cauvery basin might have also helped in the rapid transgression of the tsunami surge.

\section{Conclusions}

The combined analysis of gravity and magnetic data partially constrained by the MCS reflection profiles along the southeastern part of the ECMI provided valuable insights about the crustal architecture, breakup history and onshore-offshore tectonic linkage at the Cauvery-Palar basin. Some of the salient results from the present study are summarized below:
- Gravity derived crustal models indicate that the crust below southeast Indian shield margin is $\sim 36 \mathrm{~km}$ thick and thins down to as much as 13$16 \mathrm{~km}$ in the Ocean Continent Transition (OCT) region and increases to around $19-21 \mathrm{~km}$ towards deep oceanic areas. The faulted Moho geometry with maximum stretching in the Cauvery basin indicates shearing or low angle rifting at the time of breakup between India-Sri Lanka and the East Antarctica. However, the additional stretching observed in the Cauvery basin region could be ascribed to the subsequent rifting of Sri Lanka from India. Further, the abnormal thinning of crust at the OCT is interpreted as the probable zone of emplaced POC rocks that formed during the breakup.

- The spectral analysis of offshore magnetic anomaly data suggests that depth to the Curie isotherm is around $23 \mathrm{~km}$ in the offshore Cauvery-Palar basin.

- The crustal models, the composite magnetic and gravity anomaly maps further indicate that crust in the Cauvery-Palar offshore region is mostly segmented due to the presence of $\mathrm{E}-\mathrm{W}$ trending Precambrian mega shear structures and other major faults, which reveals blocky nature of the upper crust. This complex structural pattern will have implications on the seismogenesis of the region.

\section{Acknowledgements}

This work was carried out as part of the IITB-NIO collaborative project sponsored by the Ministry of Earth Sciences (MoES/P.O. (Seismo)/1(141) 2011). The financial support by the MoES is gratefully acknowledged. The comments and suggestions made by two anonymous reviewers greatly helped to improve the manuscript.

\section{References}

Ajayakumar P, Kurian P J, Rajendran S, Radhakrishna M, Nambiar C G and Mahadevan T M 2006 Heterogeneity in crustal structure across the southern granulite terrain (SGT): Inferences from an analysis of gravity and magnetic fields in the Periyar plateau and adjoining areas; Gondwana Res. 10 18-28.

Andersen O and Knudsen P 2008 The DNSC08 global gravity and bathymetry; European Geophysical Union meeting, April 14-18th, Vienna, Austria, pp. 1-7.

Balakrishnan T S and Sharma D S 1981 Tectonics of Cauvery Basin; Bull. ONGC India 18 49-51.

Bansal A R, Gabriel G, Dimri V P and Krawczyk C M 2011 Estimation of depth to the bottom of magnetic sources by a modified centroid method for fractal distribution of sources: An application to aeromagnetic data in Germany; Geophysics 76(3) L11-L22. 
Bastia R and Radhakrishna M 2012 Basin evolution and petroleum prospectivity of the continental margins of India; In: Developments in Petroleum Science, Elsevier Publishers, 59 432p.

Bastia R, Radhakrishna M, Srinivas T, Nayak Satyabrata, Nathaniel D M and Biswal T K 2010 Structural and tectonic interpretation of geophysical data along the eastern continental margin of India with special reference to the deep water petroliferous basins; J. Asian Earth Sci. 39 608-619.

Bastia R, Radhakrishna M and Nayak Satyabrata 2011 Identification and characterization of marine geohazards in the deep water eastern offshore of India: Constraints from multi-beam bathymetry, side scan sonar and 3D high-resolution seismic data; Natural Hazards 57 107120.

Bhattacharyya B K and Leu L K 1975 Analysis of magnetic anomalies over yellow stone national park: Mapping and Curie point isothermal surface for geothermal reconnaissance; J. Geophys. Res. 80 4461-4465.

Biswas S K, Bhasin A L and Jokhan Ram 1993 Classification of Indian sedimentary basins in the framework of plate tectonics; In: Proceedings of the second seminar on petroliferous basins of India: Dehradun (eds) Biswas S K, Alak D, Garg P, Pandey J, Maithani A and Thomas N J, Indian Petroleum Publishers, 1 1-46.

Blakely RJ 1995 Potential Theory in Gravity and Magnetic Applications; Cambridge University Press, 437p.

Chand S and Subrahmanyam C 2001 Gravity and isostasy along a sheared margin - Cauvery basin, Eastern Continental Margin of India; Geophys. Res. Lett. 28 22732276 .

Chand S, Radhakrishna M and Subrahmanyam C 2001 India-East Antarctica margins: Rift-shear tectonic setting inferred from gravity and bathymetry data; Earth Planet. Sci. Lett. 185 225-236.

Chandra U 1977 Earthquake of peninsular India - a seismotectonic study; Bull. Seismol. Soc. Am. 67 13871413.

Chandra K, Raju D S N and Mishra P K 1993 Sea level changes, anoxic conditions, organic matter enrichment and petroleum source rock potential of the Cretaceous sequences of the Cauvery Basin, India: Source rocks in a sequence stratigraphic framework, American Association of Petroleum Geologists Studies in Geology; Am. Assoc. Petrol. Geol. 37 131-146.

Chari M V N, Sahu J N, Banerjee B, Zutshi P L and Chandra K 1995 Evolution of the Cauvery basin, India from subsidence modelling; Mar. Petrol. Geol. 12 667-675.

Curray J R, Emmel F J, Moore D G and Raitt R W 1982 Structure, tectonics and geological history of the northeastern Indian Ocean; In: The Ocean Basins and Margins: The Indian Ocean (eds) Nairn A E M and Stehli F G, 6, Plenum Press, New York, pp. 399-450.

Drury S A, Harris N B W, Holt R W, Reeves-Smith G W and Wight-Man R T 1984 Precambrian tectonics and crustal evolution in south India; J. Geol. 92 1-20.

Edwards R A, Whitmarsh R B and Scrutton R A 1997 Synthesis of the crustal structure of the transform continental margin off Ghana, northern Gulf of Guinea; Geo-Mar. Lett. 17 12-20.

Gaina C, Müller R D, Brown B, Ishihara T and Ivanov S 2007 Breakup and early seafloor spreading between India and Antarctica; Geophys. J. Int. 170 151-169.

Gopala Rao D, Krishna K S and Sar D 1997 Crustal evolution and sedimentation history of the Bay of Bengal since the Cretaceous; J. Geophys. Res. 102 $17,747-17,768$.
Kaila K L and Bhatia S C 1981 Gravity study along Kavali-Udipi deep seismic sounding profile in the Indian peninsular shield: Some inferences about origin of anorthosites and Eastern Ghat orogeny; Tectonophys. 79 129143.

Kaila K L and Tewari H C 1985 Structural trends in the Cuddapah basin from deep seismic soundings (DSS) and their tectonic implications; Tectonophys. 115 69-86.

Kaila K L, Chowdhury R K, Reddy P R, Krishna V G, Hari Narain, Subbotin S I, Sollogulb V B, Chekunov A V, Kharetchko G E, Lazarenko M A and Ilchenko T V 1979 Crustal structure along the Kavali-Udipi profile in the Indian peninsular shield from deep seismic sounding; $J$. Geol. Soc. India 20 307-333.

Kaila K L, Murthy P R K, Rao V K and Venkateswarlu N 1990 Deep seismic sounding in the Godavari graben and Godavari (coastal) basin, India; Tectonophys. 173 307-317.

Krishna K S, Michael Laju, Bhattacharyya R and Majumdar T J 2009 Geoid and gravity anomaly data of conjugate regions of Bay of Bengal and Enderby Basin - new constraints on breakup and early spreading history between India and Antarctica; J. Geophys. Res. 114 B03102, doi: 10.1029/2008JB005808.

Kumar S P 1983 Geology and hydrocarbon prospects of Krishna-Godavari and Cauvery basins; In: Petroliferous basins of India (ed.) Bhandari L L, Petroleum Asia Journal, Himachal Times Group Publication, Dehradun, pp. $57-65$.

Lal N K, Siawal A and Kaul Anil K 2009 Evolution of east coast of India - A plate tectonic reconstruction; J. Geol. Soc. India 73 249-260.

Mahadevan T M 2003 Geological evolution of south Indian shield; Geol. Soc. India Memoir 50 25-46.

Mukhopadhyay M and Krishna M R 1991 Gravity field and deep structure of the Bengal Fan and its surrounding continental margins, northeastern Indian Ocean; Tectonophys. 186 365-386.

Murthy K S R, Rao T C S, Subrahmanyam A S, Malleswararao M M and Lakshminarayana S 1993 Structural lineaments from magnetic anomalies of eastern continental margin of India (ECMI) and northwest Bengal Fan; Mar. Geol. 114 171-183.

Murthy K S R, Subrahmanyam V, Murty G P S and Mohana Rao K 2006 Impact of Coastal Morphology, Structure and Seismicity on the Tsunami Surge, The Indian Ocean Tsunami (eds) Tad S Murty, Aswathanarayana U and Nirupama N, Taylor and Francis (ISBN: 9780415403801 ISBN-10: 0415403804), pp. 19-31.

Murthy K S R, Subrahmanyam A S and Subrahmanyam V 2012 Tectonics of the Eastern Continetal Margin of India, New Delhi; The Energy and Resources Institute (TERI), $184 \mathrm{p}$.

Murty G P S, Subrahmanyam A S, Murthy K S R and Sarma K V L N S 2002 Evidence of fault reactivation off pondicherry coast from marine geophysical data; Curr. Sci. 83 1446-1449.

Nemcok M, Sinha S T, Stuart C J, Welker C, Choudhuri M, Sharma S P, Misra A A, Sinha N and Venkatraman S 2012 East Indian margin evolution and crustal architecture: Integration of deep reflection seismic interpretation and gravity modelling; In: Conjugate Divergent Margins (eds) Mohriak W U, Danforth A, Post P J, Brown D E, Tari G T, Nemeok M and Sinha S T, Geol. Soc. London, Spec. Publ.

Okubo Y, Graf R J, Hansen R O, Ogawa K and Tsu H 1985 Curie point depths of the island of Kyushu and surrounding areas, Japan; Geophysics 50 481-494. 
Prabhakar K N and Zutshi P L 1993 Evolution of southern part of Indian east coast basins; J. Geol. Soc. India 41 215-230.

Radhakrishna M, Subrahmanyam C and Twinkle D 2010 Thin oceanic crust below Bay of Bengal inferred from 3-D gravity interpretation; Tectonophys. 493 93-105.

Radhakrishna M, Twinkle D, Nayak S, Bastia R and Srinivasa Rao G 2012a Crustal structure and rift architecture across the Krishna-Godavari basin in the central Eastern Continental Margin of India based on analysis of gravity and seismic data; Mar. Petrol. Geol. 37 129-146.

Radhakrishna M, Rao G S, Nayak S, Bastia R and Twinkle D 2012b Early Cretaceous fracture zones in the Bay of Bengal and their tectonic implications: Constraints from multi-channel seismic reflection and potential field data; Tectonophys. 522-523 187-197.

Rajaram Mita, Anand S P and Balakrishna T S 2006 Composite magnetic anomaly map of India and its contiguous regions; J. Geol. Soc. India 685 569-576.

Rajaram Mita, Anand S P, Hemant K and Purucker M E 2009 Curie isotherm map of Indian subcontinent from satellite and aeromagnetic data; Earth Planet. Sci. Lett. 281 147-158.

Ramasamy S M and Balaji S 1995 Remote sensing and pleistocene tectonics of southern Indian peninsula; Int. J. Remote Sens. 16 2375-2391.

Ramasamy S M, Bishop Ian and Joyce E B 2001 Tectonically induced environmental problems on and off Pondicherry coast, Tamil Nadu, India - A vision through remote sensing; Proc. Vol. of Asian Conference on Remote Sensing, pp. 666-670.

Rangaraju M K, Aggarwal A and Prabhakar K N 1993 Tectonostratigraphy, structural styles, evolutionary model and hydrocarbon prospects of Cauvery and Palar basins, India; In: Proceedings of the second seminar on petroliferous basins of India: Dehradun (eds) Biswas S K, Alak D, Garg P, Pandey J, Maithani A and Thomas N J, Indian Petroleum Publishers 1 331-354.

Rao L H J, Rao T S, Reddy D R S, Biswas N R, Mohapatra G P and Murthy P S N 1992 Morphology and sedimentation of continental slope, rise and abyssal plain of western part of Bay of Bengal; Geol. Surv. India Spec. Publ. 29 209-217.

Rastogi B K 2001 A note on the focal mechanism of Pondicherry earthquake, EQ News; DST Biannual Newsletter 2 3p.

Ravat D, Pignatelli A, Nicolosi I and Chiappini M 2007 A study of spectral methods of estimating the depth to the bottom of magnetic sources from near-surface magnetic anomaly data; Geophys. J. Int. 169 421-434.

Reddi A G B, Murthy B S R and Kesavamani M 1998 compendium of four decades of geophysical activities in Geological Survey of India; Geol. Surv. India Spec. Publ. 36.
Reddy P R, Rajendra Prasad B, Vijay Rao V, Sain K, Prasada Rao P, Khare P and Reddy M S 2003 Deep seismic reflection and refraction/wide-angle reflection studies along Kuppam-Palani transect in the Southern Granulite Terrain of India; In: Tectonics of Southern Granulite Terrain, 50. Kuppam Palani Geotransect (ed.) Ramakrishnan M, Geol. Soc. India Memoir, pp. 79-106.

Ross H E, Blakely R J and Zoback M D 2006 Testing the use of aeromagnetic data for the determination of Curie depth in California; Geophysics 71(5) L51-L59.

Sahu J N 2008 Hydrocarbon Potential and Exploration Strategy of Cauvery Basin, India; Technology Publications, 314p.

Sastri V V, Sinha R N, Singh G and Murti K VS 1973 Stratigraphy and tectonics of the sedimentary basins on the East coast of India; Am. Assoc. Petrol. Geol. Bull. 57 $655-678$.

Sastri V V, Venkatachala B S and Narayanan V 1981 The evolution of the east coast of India; Palaeogeogr. Palaeoclimatol. Palaeoecol. 36 23-54.

Singh A P, Mishra D C, Vijay Kumar V and Vyaghreswar Rao M B S 2003 Gravity magnetic signatures and crustal architecture along Kuppam-Palani Geotransect, south India; Tectonics of Southern Granulite Terrain, 50. Kuppam Palani Geotransect (ed.) Ramakrishnan M, Geol. Soc. India Memoir, pp. 139-163.

Spector A and Grant F S 1970 Statistical models for interpreting aeromagnetic data; Geophysics 35 293-302.

Subrahmanyam A S, Lakshminarayana S, Chandrasekhar D V, Murthy K S R and Rao T C S 1995 Offshore structural trends from magnetic data of Cauvery basin, east coast of India; J. Geol. Soc. India 46 269-273.

Subrahmanyam C, Thakur N K, Gangadhara Rao T, Ramana M V and Subrahmanyam V 1999 Tectonics of the Bay of Bengal, northeastern Indian Ocean: New insights from satellite-derived gravity and shipborne geophysical data; Earth Planet. Sci. Lett. 171 237-251.

Subrahmanyam V, Subrahmanyam A S, Murthy K S R, Murty G P S, Sarma K V L N S, Suneeta Rani P and Anuradha A 2006 Precambrian mega lineaments across the Indian subcontinent - preliminary evidence from offshore magnetic data; Curr. Sci. 90 578581.

Tanaka A, Okubo Y and Matsubayashi O 1999 Curie point depth based on spectrum analysis of the magnetic anomaly data in East and Southeast Asia; Tectonophys. 306 461-470.

Varadachari V V R, Nair R R and Murthy P S N 1968 Submarine canyons off the Coramandel coast; Bull. Nat. Inst. Sci. 38 457-462.

Verma R K, Rao S C and Satyanarayana Y 1993 Gravity field and evolution of Krishna-Godavari and Cauvery basins of India; Indian J. Petrol. Geol. 2 39-52. 